\title{
Symbolic Space of Writing in Decorative Kufic of Samanid Slipwares
}

\section{Introduction}

Visual forms of writing have different meanings than the writings' content. This becomes more obvious in a specific cultural context, such as the Islamic, where one can observe many inscriptions with the same content but different forms. One of these forms is the decorative Kufic of Samanid slipwares, of which various letterforms' imply symbolic meanings.

Samanid slipwares are glazed ceramics dating approximately from the $9^{\text {th }}$ to $11^{\text {th }}$ centuries $\mathrm{AD}\left(3^{\text {th }}-5^{\text {th }}\right.$ c. Hijri) in the eastern north of Iran. A major part of the decoration repertoire of these ceramics, ornamental inscriptions hold a crucial role in making invisible mystical aspects of Samanid elite beliefs visible. Diverse forms of the same phrase of Samanid inscriptions seem to be complementary explanations to the origin and developments of mystical exegesis of Qur'anic letters in Iran.

To shed light on such invisible mystical concepts, it makes sense to focus on theories concerning the relationship between writing and history. According to two prominent theories propounded by Jacques Derrida (Derrida 1997) and Walter Benjamin (Benjamin 2003), history may be better comprehended through the image system of writing instead of the sound base of speech. Both of them suggest using graphology $^{1}$, a method of analyzing handwriting for evaluating personal traits. From this viewpoint, two issues on the absent meaning of decorative inscription have not been addressed yet:

The first issue is the 'Samanid graphology' according to Derrida's cultural graphology, in which the graphology must be developed in order to become appropriate for analyzing national writings. To that end, the first part of the paper is devoted to Samanid graphology conducted in accordance with the principles of Kufic scripts

1 Graphology-the analysis of handwriting-can be, however, traced back to Aristotle (384-322 BC), for the first time was presented in a publication by Italian Camillo Baldo (1555-1635) in 1622. But, French Jean-Hippolyte Michon (1806-1881) is certainly the founder of graphology: he not only founded the Société Française de Graphologie in 1871 but also started publishing the periodical La Graphologie in addition to his two books on graphology. This French school of graphology has continued up to the present time. In 1900, Ludwig Klages (1872-1956) formed a new school in graphology. He kept the classification of the French school and added his philosophical idea on the movement and rhythm influences. Another master of graphology is the Swiss Max Pulver (1890-1953), who discovered the symbolism of space in handwriting and published it in 1931 (Nezos 1989, 7-9).

This paper was supported by Art University of Isfahan.

○ Open Access. (c) 2018 Farnaz Masoumzadeh, publiziert von De Gruyter. (œ) BY-NC-ND Dieses Werk ist lizenziert unter der Creative Commons Attribution-NonCommercial-NoDerivatives 4.0 Lizenz.

https://doi.org/10.1515/9783110619928-009 
as well as with letter interpretation in Samanid texts. Consequently, the developed method revives and reveals an invisible part of Iranian visual culture.

The second issue is how the developed graphology will be utilized for interpreting the symbolic meaning of decorative letterforms. The next part of the paper, thus, is about the analysis of three forms of Alif-the first letter of the Kufic script. As a result, it will become apparent that the mystical meaning of letterforms is a part of writing revolution profoundly connected to a previous pictorial writing system.

\section{Decorative Kufic of Samanid Slipwares}

Samanid slipwares were produced over the biggest part of the Islamic realm in the east including Iran and Transoxiana. They form the greatest part of surviving Samanid material culture, and depict a wide view of 10th century Islamic art in a small scale. ${ }^{2}$ In fact, Samanid slipwares were decorated with a spectrum of ornaments ranging from geometric and herbal to figurative and epigraphic motives.

Among them, script-bearing slipwares are regarded as a significant trend of the Samanids for both the inscriptions' contents, such as benedictions, proverbs and pious aphorisms, and their various decorative Kufic scripts. But since the meaning is almost always understood primarily according to the contents of these inscriptions, the language of visual forms has not been deciphered yet.

What is important in interpreting this decorative Kufic, is to assume it as sign-bearing letterforms. On this premise, the decorative Kufic of Samanid slipwares is possibly related to Qur'anic letter interpretation raised firstly by $10^{\text {th }}$-century exegesis and afterwards by theology, and philosophy. ${ }^{3}$ Therefore, the relationship of letter interpretation both in Samanid sciences and their epigraphic slipwares is the main underlying reason why letters bear decorative signs. The more this relationship is identified, the more Samanid Graphology comes into light.

Samanid graphology assists to re-read the decorative Kufic so as to elicit symbolic meaning of Samanid inscriptions. Graphology so far is only known as an analytic method of psychology for interpreting writer characteristics through his/her handwriting. However, cultural graphology of such historical Samanid inscriptions fits more into a framework of hermeneutical theory, which is discussed in the following part.

2 Wilkinson 1973, xlii.

3 The interpretation and mystical exegesis of Qur'anic letters became prevalent in the Samanid era. It is worth mentioning that Qur'anic letters are the words in the first verse of some of the Qur'an's chapters and since they have no meaning, they are separated into letters in order to be interpretable. This process of separation and interpretation brought numerous methods developed in other sciences. In theology, for instance, it was employed for the explanation of God's attributes, the prophet and his successors' values. And in philosophy, the numeral value of the letters was used to describe the abstract and essence of religious truths. 


\section{Writing and History}

The most important theoretical issue proposed on understanding history in post-structuralist debates is about how history will be recognized by the image system of writing-painting ${ }^{4}$ instead of the sound base of speech. One of those debates is the major focus of Jacques Derrida ${ }^{5}$ on literary theory; the other one is dispersed through the ideas of Walter Benjamin ${ }^{6}$. In general, since they believe that writing-painting reflects the history of thought, both of them come to the conclusion that the best method of reading history from artworks is graphology.

\subsection{Derrida's Deconstruction: Writing/Absence over Speech/ Present}

Derrida's theory of deconstruction is informative for paying attention to the question of how the visual language of an alphabet is intelligible. This deconstruction can be presented in three steps; first, exposing dichotomies ${ }^{7}$ of speech/writing dominating our way of thinking, then, criticizing the theory of language, and finally, suggesting a method to exit the inner sound of writing and proceed to an outer image of it.

First of all, Derrida stated his agreement with the Structuralists' stance assuming language as the origin of history and even world culture. ${ }^{8}$ But he revealed how Structuralists have always already condemned writing for being only a representation of speech under the influence of a Platonic dichotomy. He also stated that this condemnation relates to the desire for presence, in which writing is regarded as a copy of original presence. ${ }^{9}$

Besides, Derrida simultaneously realized that there are several ways of valorization and disqualification of writing at the same time in some Structuralists' works. $^{10}$ Starting to criticize other texts, Derrida gradually developed the theory of language in a deconstructive way. However this deconstruction is masterfully designed in many details, showing what Derrida thinks about the similarity of thought language to

4 Derrida 1981, 190, considered the term Writing-painting as a description for inscriptions in his work titled Dissemination.

5 Jacques Derrida (1930-2004) is a French philosopher who has a deconstructive approach on analysis of thought history. Thus he inverts writing over speech to stretch the unconscious meaning out of history.

6 Walter Benjamin (1892-1940) is a German philosopher who has a materialist approach of understanding history. In this way, he valorizes the form of arts more than the content of history.

7 Derrida exposes various binary and hierarchical oppositions such as good over evil, truth over error, etc. influencing our thinking process. His demonstrative strategy is to reverse existing oppositions.

8 Derrida 1978, 2.

9 Derrida 1997, 13.

10 Derrida 1997, 140. 
three stages of writing evolution ${ }^{11}$ is useful to analyze the visual language of historical inscriptions. ${ }^{12}$ In fact, Derrida believes that the first two elements of the evolution of writing, namely pictograph and ideograph, have been forgotten since they are substituted by the last one, named phonetic-alphabet writing. However, the knowledge of these writing systems unconsciously affects our ways of thinking. ${ }^{13}$

What attracted Derrida in surveying the three stages of writing, was the symbolic language of the ideograph. He suggested graphology ${ }^{14}$ to read other dimensions of historical meaning. He also emphasized that "cultural graphology" must be renewed and fertilized by sociology, history, ethnography, and psychoanalysis. ${ }^{15}$

\subsection{Benjamin's Materialism: Form, Allegory, and the Constella- tion of Ideas}

Benjamin's historical materialism contains the possibility of implying critical epochs ${ }^{16}$ from the history of every art form. ${ }^{17}$ We may use more specific details of his idea for our purpose and appropriately arrange it in three parts; first, concentrating on the art form of Samanid inscriptions instead of their historical content; then, applying the discovered method of Samanid graphology for perceiving the idea of an inscription, and finally, elucidating different layers of that idea.

Benjamin compares philosophy of art with literary-history to show in what ways each of them are connected with the idea of the art form. As a result, he concluded that the historical process is merely virtual while the extreme example of an art form is the idea. ${ }^{18}$

How ideas are present in art form is illustrated in Benjamin's method defined as "Interruptive method," 19 in which "ideas" correspond to objects as constellations to stars (Fig. 1). Furthermore, the constellation of ideas connects objective phenomena to one another so that ideas are considered as the objective virtual arrangement

11 Vico defines three periods of languages with reference to their owner [a language cannot have an owner]: a. "Gods age of the hieroglyphic or sacred or secret language"; b. "Heroes age of symbolic language"; and c. "men age of the epistolary or vulgar language (Vico 1948, 31-32).

12 Derrida's theory of writing aims at showing that not only speaking has the characteristics of writing, but also writing bears the meaning constructed out of the presence of being assumed in the oral model of language; Schaeffer 1990, 141.

13 Derrida 1997, 275; Derrida 1999, 4.

14 Derrida 1997, 87; Derrida 1978, 290.

15 Derrida 1997, 145.

16 Benjamin posits that every art form has a history showing critical epochs in which a certain form of art aspires to effects of a changed technical standard that can be also called a new art form.

17 Benjamin 1968, 14.

18 Benjamin 1968, 38.

19 Ferris 2008, 79. 
or objective interpretation of phenomena, but the ideas' constellation of an art form does not show the law of phenomena; it cannot even be a criterion for judging the existence of ideas. ${ }^{20}$ Therefore, in such a timeless constellation of ideas, the harmonious relationship between the art form's elements is which symbolically constitutes historical truth had an impact on that art form. ${ }^{21}$

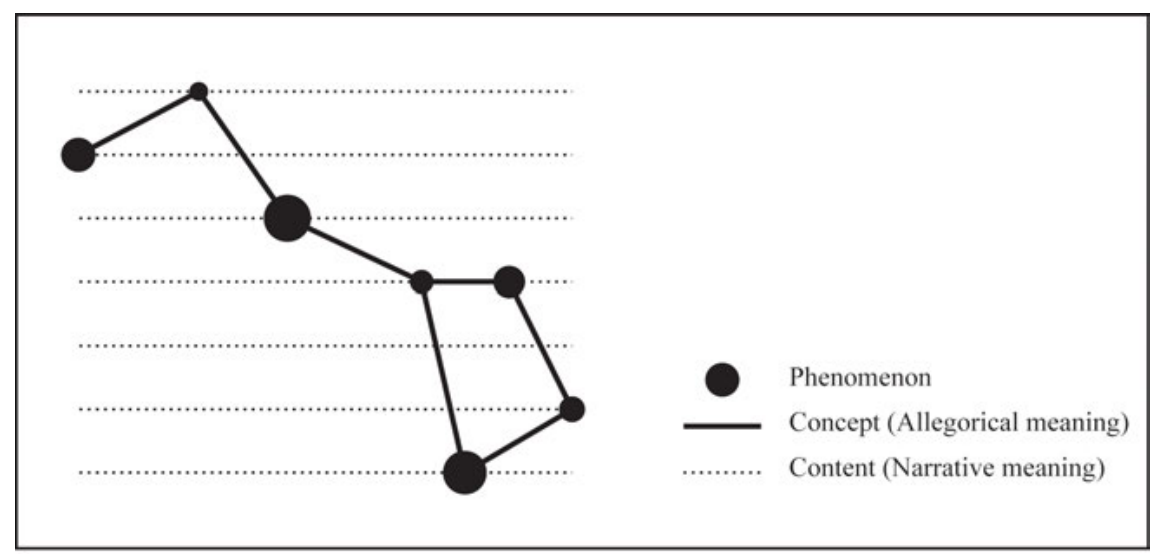

Fig. 1: Idea Constellation in Benjamin's interruptive method

The symbolic seemed to Benjamin as a term illegitimately used for the examination of every artistic form in depth. He thinks this abuse occurs wherever in the work of art the manifestation of an "idea" is declared as symbol. ${ }^{22}$ Simultaneously, the speculative concept of the allegorical is developed for the idea to provide the dark background against which the bright world of the symbol might stand out. ${ }^{23}$

It is worth mentioning that for Benjamin an allegory is not a playful illustrative technique, but a form of expression, just as speech is expression, and, indeed, just as writing is. Accordingly, he believes that an allegorical system of graphological signs is another way of expression being different from writing; ${ }^{24}$ because in graphology analysis decomposing words and letters are arranged differently from their ordinary content and meaning. ${ }^{25}$ In other words, while the content and meaning of texts are

20 Benjamin 2003, 34.

21 Benjamin 2003, 37.

22 Benjamin 2003, 160.

23 Benjamin quoted Creuzer's (1771-1858 German philologist and archaeologist) comparison of the symbol with the allegory; "The allegorical signifies merely a general concept, or an Idea which is different from itself; while the symbolic is the very incarnation and embodiment of the idea. ...In the allegorical the concept itself has descended into our physical world, and we see it itself directly"; Benjamin 2003, 161, 164-165.

24 Benjamin 2003, 162.

25 Downing 2011, 567. 
available in the ordinary arrangement of letters and words, the graphology meaning of form's texts are accessible in the constellation arrangement of letters and words.

As Benjamin mentioned, a work of art, and of course artistic inscription, serves two purposes perceived in two ways, the expression of a concept in an allegorical way and the expression of an idea in a symbolic way. ${ }^{26}$ Consequently, it is likely best to start the analysis of decorative Kufic of Samanid slipwares as an artistic inscription with letterform, leading into allegorical concepts and ending with a symbolic idea.

\section{Samanid Graphology}

Graphology is generally a method of handwriting analysis; if it is particularly enriched with $10^{\text {th }}$-century calligraphy principles and Samanid philosophic concepts just in the same way approved by both Derrida and Benjamin, this kind of cultural graphology will simply be called Samanid graphology. This developed method is remarkably similar to Symbolic graphology. ${ }^{27}$

To give a little overview of Symbolic graphology, it is interesting to notice Benjamin's explanation saying "symbolic graphology is seeking to create a space for an 'ideographic' interpretation of handwriting that is to say, a graphology that interprets script in terms of the unconscious graphic elements, the unconscious image fantasies that it contains". 28

To define the symbolic space of Samanid writing, it is sufficient to understand at least the three most important principles of graphology, ${ }^{29}$ albeit, in comparison with both the Kufic alphabet and concepts of Samanid sciences.

The first principle of graphology is the stroke, being the basis for the whole writing. It is a combination of vertical, horizontal, and diagonal lines; its correlations to each other represent the 'writing picture' or the writing character or the content of the writing image. ${ }^{30}$ Regarding to role of the stroke as a necessary manifestation of letterform existence, the stroke is very similar to either 'Proportional Script' (al-khațt al-manșūb) in Kufic principles or the concept of 'essence' in Samanid sciences. It is worth to know that Avicenna, in his concise encyclopedia on logic titled DaneshName Alai, holds that three conditions have to fulfill in order to apprehend the Essen-

26 Benjamin 2003, 161-162.

27 There are three major systems of graphology; one of them is symbolic graphology introduced by Max Pulver (1890-1953); the other one is the formlevel system or holistic Graphology developed by Ludwig Klages (1872-1956); and integrative graphology or system of stroke is another one developed by Walter Hegar, (Nezos 1989, 20, 21, 28).

28 Benjamin 1999, 399.

29 Crepieux-Jamin (Crepieux-Jamin 1963, 88) organized graphology into seven principles including speed, pressure, shape, size, continuity, direction, and order.

30 Klein 2007, 8. 
tial Universal and its Particulars: a) The Particular has meaning b) The existence of the Particular depends on the existence of the Essential Universal c) Nothing, unless the derived meaning from the essence gives meaning to a particular. ${ }^{31}$ If letterforms place instead of Particulars, it can be said their strokes are their Essential Universal that gives them meaning by identifying their category of being.

'Movement', another principle of graphology, was founded in German graphology. This graphology approach stressed the important fact that handwriting is dynamic, not static. ${ }^{32}$ 'Movement' is a criterion for analyzing how the stroke forms letters by moving away from its start point, and extending in horizontal direction. Depending on the direction of writing - in our case Kufic from right to left - when the stroke was drawn to the back or right, it implies the meaning 'past' and when it is drawn to the front or the left, it means 'future'. ${ }^{33}$ Consequently, since the vertical line does not move towards the parties, they are always considered as the present time in writing. Indeed, it can be argued that in this way, the continuity of letterform in decorative Kufic must include latent meanings about concept of 'time' in the Samanid era.

The last main graphological principle is 'Zone', applied for interpreting how the letterform is placed in the vertical axis of writing. This principle is visually very similar to several baselines of Kufic script. It is semantically supposed by Pulver that writing space is divided into three zones namely upper, middle and lower. ${ }^{34}$ So, the movement of the stroke among the vertical axis of writing shows the relationship between the intellectuality, emotionality and materiality. ${ }^{35}$ From a larger view, these kind of graphological placements for the Kufic letters contain in all likelihood precious information about the perception of 'Place', already represented symbolically in their scientific concepts. To explain briefly, the basic principles of Islamic cosmology and Islamic alchemy are the same. These principles are consistent with the unity and gradation of being; the former implies metaphysical reality which is ultimately one and not many. The latter means cosmological worlds that the sensible world is only one of many states of being or, in Sufi expression, one manifestation of 'Divine Presences'.$^{36}$ The zone in graphology principle, thus, is comparable to states of being thanks to their hierarchical orders as well as their basis of their gradational characteristics of the unity.

Space is remarkably related to human dimension. ${ }^{37}$ Therefore, since the presence of inscriptions is always considered as an Islamic stance against religious iconogra-

31 Avicenna 1971, 16.

32 Marcuse 1965, 13.

33 Pulver 1994, 22.

34 Pulver 1994, 24.

35 Pulver 1994, 32.

36 Nasr 2001, 93.

37 Nezos 1989, 20. 
phy, application of our developed graphology method for decorative Kufic of Samanid may hopefully reveal more about how Samanids as Muslims figured human and god.

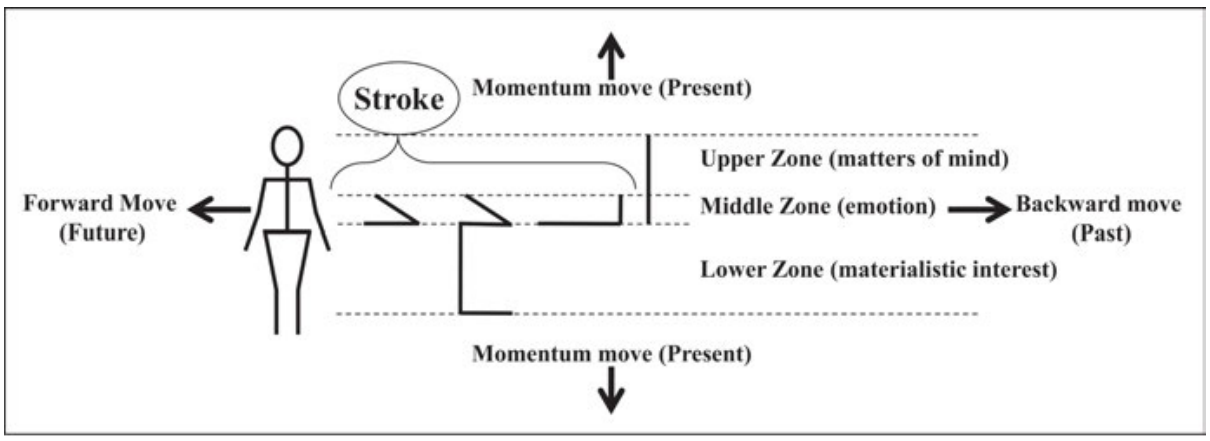

Fig. 2: Kufic Graphology: Symbolic space of Kufic writing

\section{Symbolic Language of Alif}

Being the first letter of both the Kufic alphabet and the holy Qur'an, 'Alif' - applied to the three graphology principles: stroke, movement, and zone - can be analyzed as a single stroke which moves directly vertical and uninterruptedly within two upper zones of writing. Thus, the Kufic Alif in Samanid letter interpretation can graphologically be interpreted as symbol of the main attributes of God, such as uniqueness, unity, and perfectness respectively. According to what Benjamin said about symbolic language, it can be concluded that these Samanid symbolic ideas of decorative Alif will be reconceived if allegorical concepts of the Samanids are applied for explaining how each decorative Alif is pictorially formed. In other words, it is possible to decipher three layers of decorative Kufic being composed of visual, allegorical, and symbolic language.

\section{Heart-shape Knotted Alif}

One kind of decorative Kufic Alif in Samanid slipware is the heart-shape knotted Alif. It seems that this kind of Alif visually refers to an ox head, allegorically narrating mystical self-sacrifice ${ }^{38}$ similar to a cow-sacrifice in which one sacrifices himself com-

38 In the interpretation of the fifty-fourth verse of the fifth chapter of Qur'an, al-Qushayrī (986-1074) describes God's description of his lovers who are “(...) humbles before the believers (...)” due to that they sacrifice their hearts for the beloved and sacrifice their spirit to protect the beloved (al-Bauniyyah 2016, 60). 
pletely to receive the unique essence of God, and it symbolically implies the Sufi idea about the creation of the world called 'Divine Love' when God gave his creatures their essence.

This heart-shape knotted Alif may be visually inspired by the ancient Phoenician Aleph showing the ox head (Fig. 3). This inspiration could have happened under the influence of intercultural translation during the Samanid era in a way that the visual and semantical meaning of the Phoenician Aleph as an ox head was derived for interpreting Alif as the first letter of the first chapter of the Qur'an named 'Baqara', literally meaning cow.

The visual meaning of the heart-shape knotted Alif as ox head was allegorically interpreted as self-sacrifice in a way that it can depict a picture sequence (Fig. 3). According to these assumed sequences and the Samanid mystical letter interpretation, the letter Alif has always meant both God and human ${ }^{39}$; and moreover based on its graphological zone, it can be said that the descending line depicts the essence of God coming from the highest state and the ascending line illustrates the material human receiving God's essence and coming into existence. So it is now expected to accept the Samanid mystical concept about 'Alif', which allegorized 'Alif' as a self-sacrificing man with the sign of a cow in his heart to show how the human is commended sincerely for connecting to god through self-sacrifice.

Ultimately, the symbolic meaning of Alif is most certainly intelligible after decoding its visual and allegorical aspects. Regarding these two latter meanings, and another possible pronunciation of 'Alif' as 'Alifa' meaning "he loved", the heartshape knotted Alif symbolically referred to the Sufi idea of God's attributes during the creation of the world which is called 'Divine love'. ${ }^{40}$ It is noteworthy that this symbolic meaning is also inspired by a Qur'anic verse in which God says to the prophet Muhammad: "If you expended all that is in the earth. You could not have brought their hearts together, but God brought their hearts together." ${ }^{11}$

39 In letter interpretation, Alif is phonetically almost identified as a symbol for the Arabic word for God, 'Allāh', while this word is symbolically interpreted in many dimensions (see one of the first of these interpretations al-Tustarī 2011, 12). In addition, there is a well-known prophetic Hadith which states that 'Allāh' (God) created mankind (Adam) in his own image.

40 al-Daylamī 2007, 77.

41 Qur’an, Anfāl/8:63. 

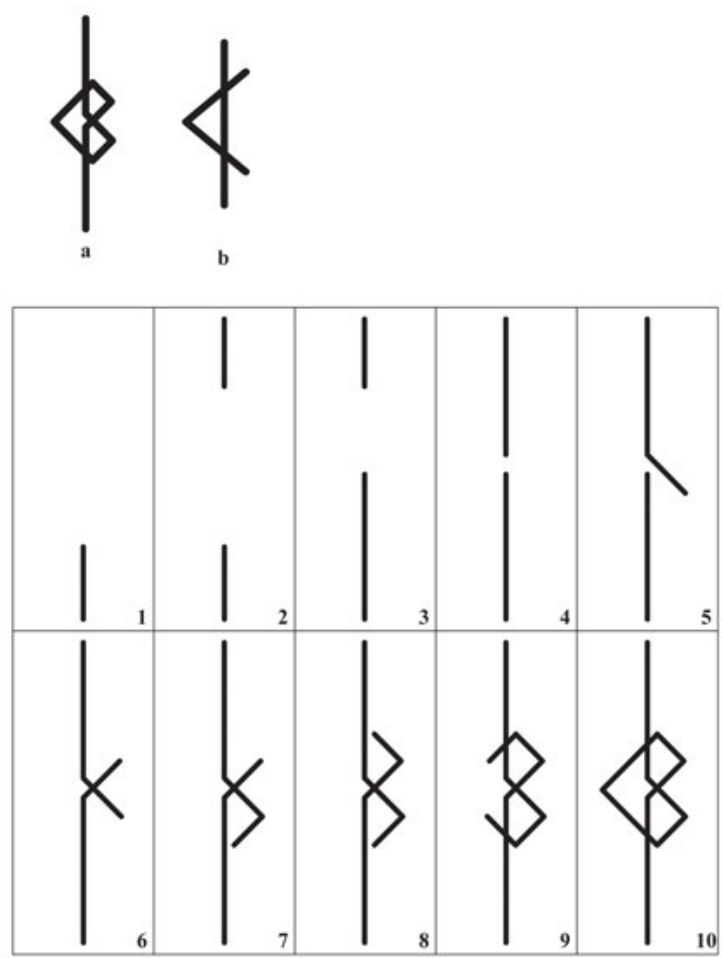

Fig. 3: a) Heart-shape knotted Alif b) Phoenician Aleph 1-12) Formation movement of the heart-shape knotted Alif in accordance with the Qur'anic letter interpretations Plaited Alif

\subsection{Plaited Alif}

The 'Plaited Alif' is a kind of ornamental Kufic Alif ligatured to its next letter named $L \bar{a} m$. This letter visually implies an ox-goad ${ }^{42}$ originating from the literal meaning of the name of Phoenician Lamed (similar to both Arabic Läm and English L). Plaited Alif allegorically means evoked divine love, as it was mentioned that either in letter interpretation, Alif is the sign for God, or in graphology the present time is inferred from it. Consequently, this form of decorative letter symbolically indicates the Sufi idea of unity of time in a way that Läm as a human goad drives Alif, to love God as well as to remind and join God in a unified moment.

Plaited Alif contains interlacing Alif with Lâm, which seems to depict the meaning of the Phoenician alphabet in which Alif and Lamed show cow and goad respective-

42 Ox-goad is an ancient hooked stick for handling and driving oxen. It is usually associated with two roles including a driver and a chaser. Accordingly, since the letterform of Kufic Lam has a hook-like form, this letter was interpreted as God's stick to guide his believers in the way of his love. 

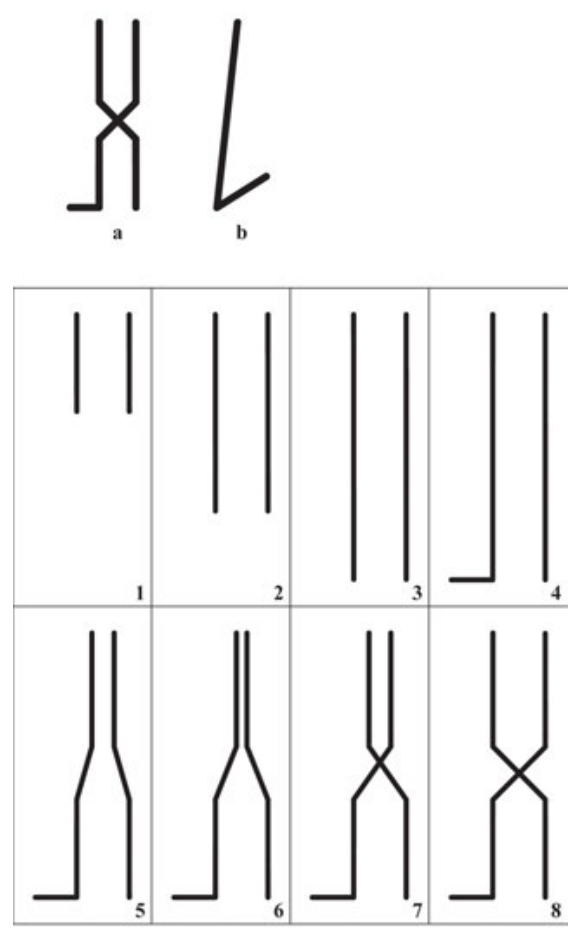

Fig. 4: a) Plaited Alif b) Phoenician Lamed 1-12) Formation movement of plaited Alif in accordance with Qur'anic letter interpretations

ly..$^{43}$ Thus, plaited Alif simply referres to an ox-goad. But its conceptual meaning depends on the allegorical reading.

The concept of plaited Alif is hidden within the allegorical relation between letters in $10^{\text {th }}$ century letter interpretation. In Qur'anic mystical exegeses, Lam stands for God's faithful servant; in addition, Alif stands for God ${ }^{44}$ in translation of "Alif Lām Mim ${ }^{\prime 45}$ in the first verse of the Qur'an. ${ }^{46}$

Graphological reading tells us the formation of Plaited Alif in sequences (Fig. 4) in such a way that the process of interlacing Alif and Läm give the impression of how the interruption of present time has been eliminated. Here it is important to firstly just remember that the vertical stroke, according to the graphology principle, is used

43 Fischer 2003, 126.

44 al-Tustarī 2011, 12.

45 Alif Lām Mìm are the most frequent Qur'anic letters as six chapters of the Qur'an begin with these letters. The significance of Qur'anic letters is unknown, and these are often attributed to the names of God.

46 Qur’an, Baqara/1:1. 
for interpreting the present time. Indeed, in Islamic mysticism, the human being is only in present time completely able to connect with the divine essence. For instance, a famous Sufic aphorism affirms that "the sufi is the child of the moment". ${ }^{47}$ In addition, another aphorism of Abū Bakr Shibli (861-946) talking to his follower is that "your moments are disjoined, whereas mine do not have any limits". ${ }^{48}$ Since according to Sufism, the moment is both recognized as present and serves to realize inseparable uniqueness, the simple Alif developed to Plaited Alif to symbolize the unity of moment.

\subsection{Foliated Alif}

The visual form of foliated Alif was additionally affected by several ancient letterforms, such as Pahlavi Ra, Nun, and Waw, through which it has obviously been under the influence of Phoenician Resh. Taking into consideration the Phoenician meaning of Resh, it is probable that foliated Alif signifies head. In an allegoric layer, the form of the leaf substituted with the head form of Alif can be appropriately interpreted at first as growing head, and secondly as illuminated person owing to the analogy between mystic travelers and leaf that moves towards light. These allegorical meaning was translated into "perfect human" in the symbolic graphology of the Samanids. For instance, when Avicenna, in his al-Shifa provides the example of humanness to define the relationship of form [essence] with matter, motion and accidents-four aspects of every body-he states that human form is a unified soul with three subsidiary parts consisting of a vegetative, animal and rational soul. ${ }^{49}$ This combination of human's unified soul is somehow analogous to Kufic foliated Alif, which seems to be a combination of the vegetative and rational soul.

The form of the simple Kufic Alif is similar to these three letterforms of Pahlavi; actually, all of these mentioned letterforms are simply drawn by a single vertical stroke. What Pahlavi letters most affect on the decoration of Foliated Alif, is its resemblance to the Phoenician Resh written with an increasing vertical line ending in a triangle form. In summary, the similarity of simple Kufic Alif and Pahlavi Ra inspires calligraphers to come up with the idea that Alif can be decorated with its phonetically similar equivalent-Pahlavi $R a$ in ancient Phoenician script-in a way that the leaf end of the foliated Alif corresponds with the triangle end of the Phoenician Resh, which visually signifies head. ${ }^{50}$

The foliated Alif is metaphorically conceived as growing head, or even as illuminated man in harmony with the Qur'anic letter interpretation considering Alif as

47 Chittick 1992, 172.

48 Avery 2014, 19.

49 Avicenna 2009, 45-47.

50 Fischer 2003, 126. 

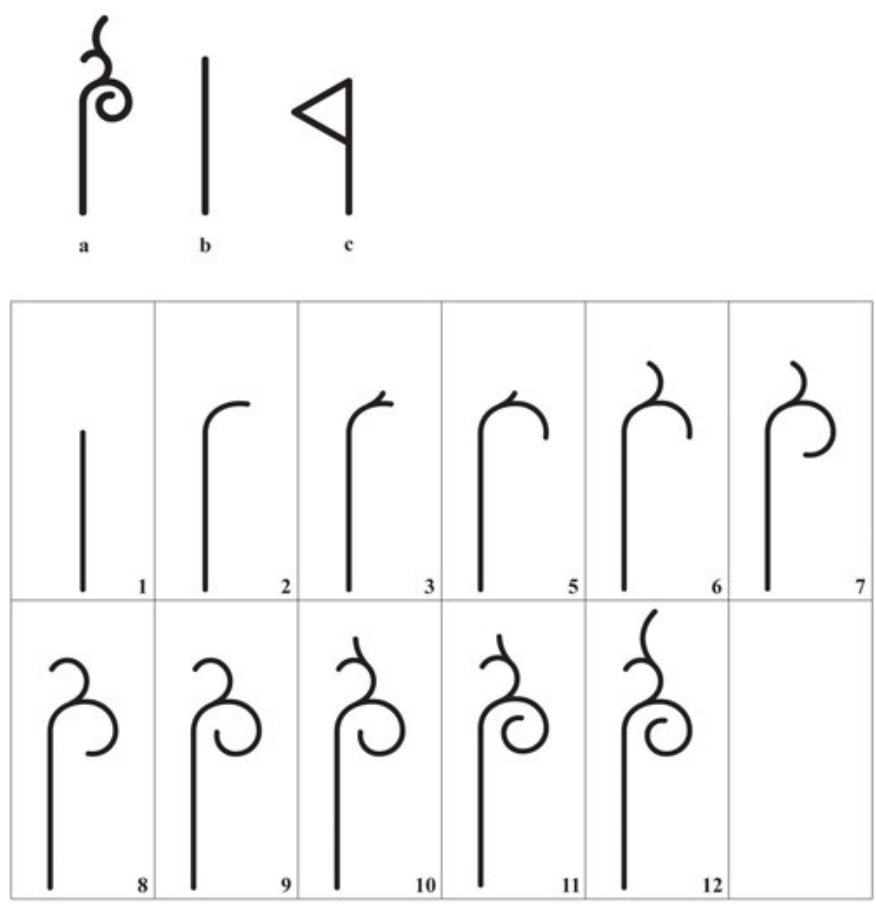

Fig. 5: a) Foliated Alif b) Pahlavi Ra c) Phoenician Resh 1-12) Formation movement of foliated Alif in accordance with Qur'anic letter interpretations

human. This conception may be inspired by Syriac and Hebrew Alif as well as be interpreted under the influence of the Jewish Kabbalah tradition depicting Alif as both the root of the ten commandments and the human ear-the temple of the sanctuary-by means of which man perceives the word of God. ${ }^{51}$ This symbolism clearly refers to the perfectness of Alif by illustrating the highest potency of God. ${ }^{52}$ This is also validated by our graphology analysis.

Let us explore how the visual form of the foliated Alif also implies perfection (Fig. 5). Based on graphological zones, the foliated Alif is an increasing stem starting from the lowest zone, passing through all of the previous zones, and finally, in addition to reaching the highest zone, leaf and dotted fruit stalk from the stem. This conquered Alif highlights the intellectual zone with the leaf sign and displays the perfect human who can perceive and gain all the attributes of God. The symbolic role of the tree as a perfect human is utilized in Samanid interpretation: For example Ibn

51 The Hebrew word for 'ear' is 'ozen' which began with Alef (Scholem 1987, 128).

52 Scholem 1987, 128. 
Bābūya/Babawayh (2001) allegorizes perfect faith as a fruitful tree..$^{53}$ Likewise, the next century theologist Abū Hafṣ 'Umar al-Nasafī (1067-1142) widely describes this allegory: in the same way that the fruit arrives at the potential existence of its original seed, the perfect human is somebody who achieved all the attributes of its original essence. $^{54}$

\section{Conclusion}

Historical inscriptions present most of their former meaning since now the way of reading the writing form in connection with the according period's sciences is certainly known. This reading seems to be a graphology system definitely being available in all times, because its three main principles (including stroke, movement, and zone) can be derived from the metaphysical concepts of one's era (containing essence, time, and place). Moreover, this meaning system made it possible to understand three language layers of writing, with regard to visual, allegorical, and symbolic relation of letterform to its time concepts.

In the same way, visual forms of decorative Kufic of Samanid slipware in relationship with Qur'anic letter interpretation confront us with a particular graphological system. In this meaning system, at first, pictographic meanings of ancient Phoenician letters define why decorative elements are added to letters, and then allegorical relations interpret how simple meanings of letterforms may be gradually changed into symbolic ones.

The symbolic meanings of decorative Kufic of Samanid slipwares are just Samanid mystical constellations of ideas; however, there are more imaginable constellations in the sky of Samanids writing that can be read with not only historical but also contemporary allegorical relations.

\section{Bibliography}

Avery, Kenneth (2014), Shibli: His Life and Thought in the Sufi Tradition, Albany. Avicenna (1971), Avicenna's treatise on logic. (A concise philosophical encyclopaedia) and autobiography, transl. by Farhang Zabeeh, The Hague.

Avicenna (2009), The Physics of The Healing. A Parallel English-Arabic Text in Two Volumes, transl. by Jon McGinnis, Provo.

al-Bauniyyah, Aishah (2016), The Principles of Sufism, transl. by Th. Emil Homerin, New York.

Benjamin, Walter (1968), "The Work of Art in the Age of Mechanical Reproduction," in: Illuminations, ed. by Hannah Arendt, transl. by Harry Zohn, New York, 217-252.

53 Ibn Bābūya 2001, 795.

54 Nasafī 2007, 179. 
Benjamin, Walter (2003), The Origin of German Tragic Drama, transl. by John Osborne, London. Benjamin, Walter (1999), “Graphology Old and New," in: Selected Writings. Vol. 2, transl. by John Osborne, London, 398-400.

Chittick, William C. (1992), Faith and Practice of Islam: Three Thirteenth-Century Sufi Texts, Albany. al-Daylamī, Abū al-Ḥasan 'Alī ibn Muḥammad (2007), Kitāb Ațf al-alif al-ma'lūf 'alā al-lām al-ma'țūf, ed. by Joseph Norment Bell and Ḥasan Mạ̣mūd 'Abd al-Lațîf al-Shāfi'ī, Cairo.

Derrida, Jacques (1981), Dissemination, transl. by Barbara Johnson, Chicago.

Derrida, Jacques (1997), Of Grammatology, transl. by Gayatri Chakravorty Spivak, Baltimore/London. Ferris, David S. (2008), The Cambridge Introduction to Walter Benjamin, Cambridge.

Fischer, Steven Roger (2003), History of Writing, London.

Ibn Bābūya, Muḥammad b. 'Alī (2001), 'lllal al-sharāyi', Qom.

Klein, Felix (2007), Gestalt Graphology (Exploring the Mystery and Complexity of Human Nature through Handwriting Analysis), New York/Bloomington.

Marcuse, Irene (1965), Guide to Personality through Your Handwriting, New York.

Nasafi, Azizoddin (2007), Le livre de l'Homme Parfait (Kitāb al-Insān al-kāmil) (Bibliotheque Iranienne 11), transl. by Marijan Mole, Teheran/Paris.

Nasr, Seyyed Hossein (2001), Science and Civilization in Islam, Chicago.

Nezos, Renna (1989), Graphology: The Interpretation of Handwriting, Channel Islands (Guernsey).

Pulver, Max (1994), The Symbolism of Handwriting, transl. by lan Stirling and Monique Stirling, London.

Schaeffer, John D. (1990), Sensus communis, London.

Scholem, Gershom (1987), Origins of the Kabbalah, transl. by Allan Arkush, Princeton.

al-Tustarī, Sahl b. 'Abd Allāh (2011), al-Tustarī, Tafsīr al-Tustarī (Great Commentaries on the Holy

Qur'ān), transl. by Annabel Keeler and Ali Keeler, Kentucky/Jordan.

Vico, Giambattista (1948), New Science, New York.

Wilkinson, Charles K. (1973), Nishapur: Pottery of the Early Islamic Period, New York. 
